\title{
The Competent Citizen: Exploring the Normative Side of Qualified Notions of Citizenship
}

\author{
Angela Kallhoff $\mathbb{B}$ \\ Faculty of Philosophy and Education, University of Vienna, Vienna, Austria \\ Email: angela.kallhoff@univie.ac.at
}

How to cite this paper: Kallhoff, A. (2020). The Competent Citizen: Exploring the Normative Side of Qualified Notions of Citizenship. Open Journal of Political Science, 10, 589-606.

https://doi.org/10.4236/ojps.2020.104035

Received: June 5, 2020

Accepted: August 14, 2020

Published: August 17, 2020

Copyright ( 2020 by author(s) and Scientific Research Publishing Inc. This work is licensed under the Creative Commons Attribution International License (CC BY 4.0).

http://creativecommons.org/licenses/by/4.0/

\begin{abstract}
Citizenship is a key notion in political philosophy. Its main content has been discussed in terms of rights and duties. This contribution argues that a recent debate on qualified notions of citizenship sheds new light on the normative discussion. Citizenship is no longer regarded as a unified notion; instead rights, duties and even virtues of political persons are part of a discussion on "economic citizenship", "the educated citizen" and "environmental citizenship". This leads to a re-assessment of citizenship in terms of "competences" and its enabling conditions.
\end{abstract}

\section{Keywords}

Citizenship, Economic Citizenship, Education, Environment, Competence

\section{Introduction}

The concept of citizenship is not only a key concept in political philosophy; it is also one of the notions, which has been reasoned in a variety of completely different ways. In political liberalism, the concept of citizenship is closely linked to basic rights and to principles of fairness. In particular, the citizen is endowed with a sense of justice and with the capacity to develop a life-plan (Rawls, 1999: pp. 41, 358-360, 433, 442-446). Citizens should also have access to a range of the most basic primary goods, including a comprehensive set of freedoms (Rawls, 2005: p. 6). Civic republicanism instead highlights the virtues of citizens (Sunstein, 1988; Viroli, 1999). It also focuses on how the notion of a "common good" can best be framed in contemporary approaches to democracy (Pettit, 1997; Sewing, 1993: pp. 7-32; Sunstein, 1988). The citizen should be committed to the public good; simultaneously, the citizen should develop a range of civic virtues 
(MacIntyre, 1995, 2007). In theories on deliberative democracy, citizens are interpreted as persons who deliberate in a public forum about issues of common concern and who assemble political power by generating a public sphere (Habermas, 1994). Moreover, citizenship has also been debated in approaches to civil society and its values (Barber, 1999; Havel, 2000; Seligman, 1992). Due to concerns about migration, the relationship between the nation state and supra-national organizations has also been re-interpreted and changed. In this context, cosmopolitan citizenship has been at the center of concern (Appiah, 2007; Nussbaum, 1996). If there is one common trait of all these approaches taken together, it is the normative interpretation of citizenship. As citizens, persons should be allowed to participate in basic rights, persons should engage for the common good and develop virtues, they should be regarded as cosmopolitan citizens.

Recently, the debate on normative citizenship has been extended in discourses on what might be called "adjective concepts of citizenship". Instead of confining the debate of citizenship to the most basic elements of citizenship and its normative content, this discussion is a part of discourses in a variety of fields, including applied ethics. Some of these discourses relate to a particularly problematic field of citizenship performances, others highlight conditions of citizenship performances in modern and differentiated societies. Notions of qualified citizenship comprise “ecological citizenship" (Bell, 2005; Dobson, 2003; Hailwood, 2005), “economic citizenship" (Ulrich, 2008), “consumer citizenship” (Barber, 1999), “educated citizenship" (Gutman, 1999), and “digital citizenship" (McCosker et al., 2016).

In this contribution, I wish to defend the claim that these contributions are much more important for the debate on citizenship that usually admitted. In particular, qualified notions of citizenship highlight important and often neglected aspects of citizenship theory: They argue that even though citizenship is a normative concept, the claims are only reasonable when completed by another insight: in order to define the content of normative citizenship, it is important to acknowledge the enabling conditions of specified elements of democratic citizenship. In this contribution, I shall abbreviate this as "citizenship competences".

Overall, this discussion is in line with former approaches to citizenship in political philosophy as a normative project. In that context, notions of citizenships rest on basic entitlements and of duties. Yet, different from the approach to citizenship through the lenses of philosophical programs such as political liberalism, republicanism and deliberative democracy, recent discourse on qualified citizenship tries not only to render the normative claims for participation and for inclusion more precise. It also argues conditions that enable persons to become citizens in the full sense of normative citizenship.

Competences have two sides. On the one hand, they need to be supported by institutions that care for their development. In this respect, competences are comparable to the category of capabilities which have been proposed by Martha 
Nussbaum in order to define basic functions of a basically good personal life (Nussbaum, 2000). Different from capabilities of persons, competences of citizens are defined in relationship to the basic functions and contributions of citizens to public life and to political life. On the other hand, the competent citizen enjoys participation in modern societies and their institutions in the full sense: She is not only able to vote, but also to participate in the public sphere, in the formation of the public sphere and sub-spheres of civil life and in the economic sector.

This contribution explores adjective concepts of citizenship as arguments in favor of taking a second look at citizenship competences. This analysis also prepares a normative claim which I cannot argue to the full extent in the context of this contribution, but which is one of the immediate consequences of this approach to citizenship: Democracies need to support the enabling conditions of citizenship competences. In modern and differentiated societies, the enabling state does not only have to care for rights, but also for competences of citizens in order to fully participate in democratic life.

This contribution is divided in three sections. In order to introduce the debate on qualified concepts of citizenship, the first section discusses three examples. It gives a brief sketch of the notions of "economic citizenship", the "educated citizen", and "ecological citizenship", respectively. It also explains the connection with normative concepts of citizenship as reasoned in the big programs of political philosophy. The second section elaborates the concept of "competence" in the context of "citizenship competences". On the one hand, a competence addresses a minimum that citizens have a right to receive in all sorts of circumstances; on the other hand, it addresses enabling conditions for fulfilling a role in a specified context. It is important to highlight both sides of the concept. Section three discusses consequences of this suggestion to the understanding of citizenship in political philosophy. It argues that the concept of a citizenship competence includes a new perspective on the constraints of citizenship performance as well as on the conditions of being capable to fully enjoy citizenship. At the same time, it is a concept that pays tribute to conditions that go beyond a single person's willingness and capacity to contribute to democracy. It highlights constraints that go beyond constitutional guarantees of democracy.

\section{Concepts of Qualified Citizenship}

Recently, citizenship has been discussed in highly specialized discourses in philosophy. In order to respond to the need to elaborate on citizenship as tied to distinct spheres of justice, authors have turned to "adjective" concepts of citizenship. That is, they do not discuss citizenship per se. Instead, they discuss "economic citizenship", "ecological citizenship" or "educated citizens". Before addressing these three examples against the background of political philosophy, it also has to be said that the debate on qualified notions of citizenship is much broader than my brief discussion indicates. In the following discussion I will focus on the contributions that address citizenship in a constructive and in a nor- 
mative sense in the context of approaches to political philosophy.

\section{1) Economic citizenship}

Peter Ulrich discusses the concept of "economic citizenship" in the context of a comprehensive approach to economic ethics (Ulrich, 2008). In particular, Ulrich develops an approach to the private sector as part of democracy, and explores republican citizenship in that area of democracy (Ulrich, 2008: pp. 1-9, 79-89). His main argument is, broadly conceived, that in democracy performances of the economic sector should be evaluated against the background of a valuable life of citizens. The private sector should be held responsible for contributing to the good life of citizens. Simultaneously, participation in economic performances of citizens is interpreted as just another way to participate in the political life of a democratic state (Ulrich, 2008: pp. 142-145). In defending this view, Ulrich introduces a fundamental critique of theories of the private sector based on the interpretation of economics as value-free enterprise. His theory is based on a theoretical approach to economy as explicitly normative theory. ${ }^{1}$

In one respect, the debate is closely related to recent discussions of civic republicanism. Ulrich wishes to tie the notion of "citizenship" to the concern for the common good, to virtues of political persons even (Ulrich, 2008: pp. 287, 311). In particular, virtues build a bridge between the political sector and the economic sector. Ulrich argues that persons should fulfill their roles as citizens and as participants in the private sector simultaneously by means of realizing civic virtues (Ulrich, 2008: pp. 217, 226-230). In another respect, Ulrich's proposal is close to liberal democracy, he is particularly interested in "citizenship rights". Ulrich even argues for access rights of citizens to the economic sector. ${ }^{2}$ As citizens, persons deserve access to jobs and to wealth-generating structures.

Even though Ulrich's program is closely tied to the big programs of democracy, this approach also differs from just applying general insights in democracy to specific areas of citizenship. Firstly, citizenship is not identified with a range of rights, including the rights to work, to economic participation and to economic freedoms alone. It would, e.g., be possible to define citizenship in terms of economic freedoms and to develop citizenship freedoms accordingly. ${ }^{3}$ Instead, the claim for virtues of citizens is completed by also highlighting the responsibility of persons to claim participation in economic performances. Secondly, the economic sphere is not regarded as a separate sphere, in particular not as a sphere that is separate from spheres of political life which usually provide the appropriate reference for citizenship discourse. Instead, citizenship includes a specification with respect to the sphere of economics, yet without losing its normative

${ }^{1}$ This part of his theory is well-developed, but not in the focus of my discussion. For the explanation of how economics relates to values, see Ulrich (2008: pp. 80-82, 86, 101, 119, 111-184).

${ }^{2}$ Even though both need to be balanced accordingly, the combination of virtues and rights has been defended in discourse on civic republicanism. Sunstein argues that this is a distinctive feature of "civic republicanism" as opposed to historic republicanism (see Sunstein, 1988). It pays tribute to liberal democracy, yet simultaneously focuses on a duty of citizens to contribute to the common good (see Pettit, 1997; Viroli, 1999).

${ }^{3}$ One well-known approach in this direction has been developed by Friedman (2002) and Friedman \& Friedman (1990: pp. 65-67). 
content. Citizens are political persons who should be in a position to reap the fruits of the economic sector; simultaneously they have responsibility for developing virtues that enable them to accomplish this goal. As I shall argue in section 2 , it is this double face of a normative approach to citizenship that is best reasoned in terms of "competences".

\section{2) The educated citizen}

The second example for a recently intense discourse on qualified concepts of citizenship is the discourse on "citizenship education". Again, this section only highlights aspects of that discourse which has a long history in political philosophy as well. ${ }^{4}$ In political philosophy, it has frequently been argued that persons have a right to receive some education as a "moral promise" given by the nation state. ${ }^{5}$ Today, this claim is supported by a debate on the shape and the contents of citizenship education. In that context, authors in political philosophy have also highlighted that citizenship education, if supported by the nation state, is a delicate matter. Instead of guaranteeing access to insights in democracy and politics, governments might be tempted to abuse citizenship education in order to support political goals. ${ }^{6}$

As for debating the realistic conditions of performing as a citizen, the problem is obvious: On the one hand, persons cannot take part actively in political life, unless they are equipped with basic skills, including the capacity to read and to argue. In order to understand the main functions and mechanisms of political life and in order to be capable of forming a political judgment, persons need to be educated. They need to develop their intellectual capacities and their capacities to judge. This claim has been reiterated in recent debates on citizenship. The precise content of citizenship-education is of course controversial. As one proponent of citizenship education, Amy Gutman defends the view that citizens need to be in a better situation than being equipped with minimal literacy in order to read and understand also basic political texts (Gutman, 1999, 1989). Citizenship education also needs to include knowledge about the main political texts of a political society, but also competences that include the exchange of arguments and deliberation in the public sphere. In sum, Gutman supports the view that democracy needs "conscious social reproduction" which includes the training of argumentative skills (Gutman, 1989: p. 77). Yet, authors in political philosophy also argue much more comprehensive claims. Martha Nussbaum states that students need to learn about life-forms all over the world in order to be prepared for cosmopolitanism. This is, again, a comprehensive claim which includes a vision of citizenship that goes beyond the modest goal of this contribution. In particular, Nussbaum also recommends that students should be pre${ }^{4}$ Whether or not the education of children should be integrated into family life or should be transferred to the nation state, is a question that was debated controversially in ancient times. See the debate between Plato and Aristotle (Aristotle, 2013: pp. 31-34 (1263a-1264b), 223-37 (1337a-1342b); Plato, 2008: pp. 70-114 (375c-412b), 159-89 (449a-471c)).

${ }^{5}$ For an overview, see [deleted for blind review].

${ }^{6}$ For a historic note on the dilemma of citizenship education and the potential intrusion of the nation state into the private sphere of citizens, see von Humboldt (1903: pp. 97-254). 
pared for learning about the lives of people in studying literature; and they need to train the capacities of imagination in order to prepare for a truly global world (Nussbaum, 1996, 1997).

Yet, on the other hand, citizenship education is a debate on constraints of governmental power. In order to respect the intellectual freedoms of persons, the nation state should refrain from educating citizens in another sense. Even though many agree that education should be supported by the nation state, diversity in education and freedom of shaping the content is also an important right of the institutions providing education. As Humboldt already noted, the limits of the nation state need to be defined along the lines of educating persons as autonomous beings on the one hand and sheer indoctrination on the other hand (von Humboldt, 1969). Therefore, a sharp line needs to be drawn between interests of the nation state in forming citizens on the one hand and interests in educating persons in order to support their capacity to perform as citizens on the other hand.

The insights that citizenship education is necessary, even though the limits of the role of the nation state need to be shaped thoroughly, has been reiterated throughout the history of philosophy. Yet, recent debate on the "educated citizen" is new in at least one respect. Authors in political philosophy are aware that education in terms of literacy etc. is not sufficient for being capable of performing as a citizen. Instead, authors that support liberal democracy also claim that citizenship education comprises the teaching of mutual respect and the training of virtues that are needed in order to exchange rational arguments accordingly (Macedo, 1990). Yet, on a very basic level, persons also need to be ready to train their competences and to develop citizenship skills by will. The twist from citizenship education to "educated citizens" is the turn I am most interested in. It highlights the delicate balance between personal engagement for becoming a "full citizen" on the one hand and the need to support this endeavor on the other hand. In particular virtues such as capacities to listen to other citizens, to argue in a rational way and to develop skills that are needed in a deliberative public sphere need to be learned and trained. ${ }^{7}$ Again, these two sides are best expressed by highlighting the concept of "competence".

Before drawing further conclusions regarding citizenship comptences, a third example of a vigorously debated qualified concept of citizenship shall be recalled. This is the notion of "ecological citizenship".

\section{3) Environmental citizenship}

It has been argued that planet earth is in a deep environmental crisis, manifesting itself as climate change, environmental pollution and the overall degradation of the natural environment. In the context of political philosophy, the diagnosis of an ecological crisis has also been tied to the debate on citizenship. In particular, some authors claim that both the crisis and remedies to the crisis need to be embedded in the debate of a normative concept of citizenship. ${ }^{7}$ For the argument that political liberalism cannot survive without a layer of virtues that liberal citizens possess, see Galston (1991). 
Therefore, environmental duties as well as environmental rights shall be integrated into a more comprehensive normative notion of citizenship (Bell, 2005; Dobson, 2003; Hailwood, 2005; Doherty \& de Geus, 1996). I shall not get into the details on these proposals of "environmental citizenship" and "ecological citizenship" here. Instead, I wish to highlight two aspects that go hand in hand with a discussion on citizenship competences.

Firstly, normative resources for arguing that citizenship includes both environmental rights and duties result from an apprehension of the citizen as a person who is not only part of a political society, but whose membership is framed in normative terms. Citizens are endowed with most basic rights. Following Rawls, citizens regard each other as free in that they have a concept of the good life (Rawls, 2005: p. 30). Yet, the other side of this normative interpretation also needs to be mentioned: "A second respect in which citizens view themselves as free is that they regard themselves as self-authenticating sources of valid claims. That is, they regard themselves as being entitled to make claims on their institutions so as to advance their conceptions of the good" (Rawls, 2005: p. 32). Inasmuch as access to basic natural goods such as water and fresh air as well as access to an intact environment count as basic entitlements, they need to be included in theorizing citizenship (Gleick, 1998; Shue, 1999; Caney, 2010). Following proposals for "environmental citizenship", citizens have environmental rights that need to be respected and accommodated by political institutions. On the other hand, citizens also bear responsibility, at least in terms of fully cooperating with respect to fundamental principles of a well-ordered society (Rawls, 2005: pp. 11-13).

As for environmental citizenship, which is a normative concept of citizenship as members of a political society that is related to the natural environment, the debate has recently focused on civil virtues. Whereas some authors defend the view that institutions need to support a fair distribution of natural goods and that it is up to institutional ethics to frame this challenge (Wissenburg, 2006; Eckersley, 2004), others argue that environmental virtues need to be an integral part of green politics and of a normative concept of citizenship likewise (Barry, 1999; Cafaro \& Sandler, 2010; Thompson \& Bendik-Keymer, 2012). The interesting turn in this debate is not the debate on environmental virtues, which has been part of environmental ethics for a while. Instead, the interesting twist is that environmental virtues, such as "simplicity", "mindfulness" and "respect" are not regarded as private virtues. Instead, they are claimed as virtues of citizens who also bear responsibility as citizens. The concept of "environmental citizenship" includes an extension of basic rights in terms of environmental rights, as for instance the right to water. ${ }^{8}$ It also claims citizenship duties in terms of realizing an attitude towards nature as a citizen that coheres with green virtues.

In comparing the proposals and in reconsidering debates on qualified concepts of citizenship, two insights can already be summarized. Firstly, even ${ }^{8}$ For an overview over the recent debate on water ethics as political ethics, see the contributions in Ziegler \& Groenfeldt (2017). 
though qualified concepts address concrete and distinct problems, and often in a critical way, they are not detached from the big themes in political philosophy. Even though always related to a specified area of political life, they work on the most basic normative ingredients in citizenship, that is the issues of basic rights and the duties of persons as citizens. In that respect, they do not amount to a new approach to citizenship. Instead, they draw on insights that have been reasoned as crucial insights in normative approaches to citizenship. ${ }^{9}$ I shall call this part of the program of qualified citizenship theories the extensionist thesis. Authors in the field of qualified citizenship apply basic normative claims to particular areas of concern, as for instance to the problem of economic participation and performance, to education and to environmental exigencies.

Secondly and different from former debates on citizenship, the qualified concepts also provide a new focus of concern: They are not restricted to talk on rights and duties; instead they rely on a view of citizens as persons that need to be supported and equipped for being in a situation to really participate responsibly in democracy. This second part is best framed as a competence thesis: In order to perform as citizens in normatively demanding areas, citizens need to be equipped with citizenship competences. This claim needs to be explained.

\section{Citizenship Competences}

Authors who defend qualified notions of citizenship in political philosophy do not reject the normative implications and arguments that have been reasoned in political philosophy when discussing citizenship. Quite the opposite is true: They are in line with theories of citizenship that emphasize a normative content of that concept. Citizenship is discussed in the context of basic entitlements of persons as members of a political society; citizenship is framed in terms of civic virtues and deliberative capacities; citizens are regarded as bearing responsibility for the common good and for the natural environment. The visible shift of qualified concepts of citizenship is one towards a specific content of duties and rights as related to particular public goods. The basic insight is that the content and the normative principles related to citizenship need to correspond to the various sub-spheres of political society. In particular, authors try to give a more concrete picture of duties and rights that correspond to the sub-spheres respectively (Kallhoff, 2011).

Yet, in another respect, recent approaches to qualified citizenship defend an important and unique insight. Instead of reiterating normative claims, they argue that citizens need to be supported in developing citizenship skills. This is the claim that citizenship needs to be supported, possibly even enabled by strengthening citizenship competences. ${ }^{10}$ This does not imply that the central insights of normative approaches to citizenship on a more general level do not apply any

${ }^{9}$ This discourse can also be tied to human rights of the second generation. For this, see the original idea of distinguishing groups of rights by Marshall (1964).

${ }^{10}$ This question has a theoretical as well as an imminently political and practical side. In this contribution, I focus on the theoretical side. 
longer. Political philosophers share the view that citizens deserve the guarantee of basic rights; they also agree on the relevance of some political definition of the common good and corresponding political virtues. They also agree that the public forum is the forum for citizens to debate on issues of public concern. Yet, authors who discuss particular competences of citizens to participate in the economic sector, to address the natural environment, to understand and interpret political claims accordingly and to argue in the public sphere break with another premise: They think that reasoning and claiming basic rights and duties of citizens do not suffice any longer. Instead, political philosophy has to explicate another important issue: This is the premise that persons grow up in societies that either equip them with the competence to participate actively in a variety of spheres of cooperation and performances, including the economy, the public sphere, and environmental conservation; or societies fail to do so. ${ }^{11}$ To some extent, Rawls appears to think that the capacities to fully cooperate as a citizen are automatically provided by fair societies: "Since we begin from the idea of society as a fair system of cooperation, we assume that persons as citizens have all the capacities that enable them to be cooperating members of society" (Rawls, 2005: p. 20). Authors who reason qualified concepts of citizenship to do not only reject this claim. They also take a closer look on the prerequisites of "full citizenship" in diversified societies.

According to recent debates of qualified notions of citizenship, even citizens who have had the good luck to grow up in liberal democracy will not be automatically in a situation to engage in public debate, to participate in economic performances or to engage for environmental conversation. Instead, citizens need to be equipped with competences which, to some extent, need to be supported by governments and by the political society.

Theories of qualified citizenship do not only make this already demanding claim. They also include proposals for 1) justifying these claims in the context of a normative approach to citizenship and 2) for reasoning the conceptual implications of this claim. Whereas (1) is closely tied to the particular sphere of citizenship performances and has already been portrayed in outlining the "extensionalist thesis" of normative concepts of citizenship, the remainder of this contribution works on (2). I shall discuss the arguments for citizenship competences in two steps. Firstly, I shall argue that the concept of "competences" needs to be regarded as a very basic concept in framing the claims of qualified citizenship accordingly. As a two-sided concept, it needs to be discussed thoroughly. Secondly, I shall argue that this focus has a range of implications and consequences for citizenship theory more generally.

The category of a "competence" is a coin that has two sides. On the one hand, a competence is a prerequisite for being in a situation to deliver services and to accomplish functions in a complex system. The competent reader knows how to read a book; the competent citizen instead knows how to participate in the eco-

${ }^{11}$ In the context of this contribution, I abstract from the fact of migration. 
nomic sphere, in politics, and in an education system. The concept of a competence is also close to a functional interpretation. A competent person knows to act in a social context whose standards of "best performances" are agreed upon as normative standards. A competent speaker knows the rules of a language; moreover, she knows how to apply the rules correctly. Yet, the competent speaker is also the person without whom language in its current form would no longer exist. The competent speaker even transforms language, together with all the other competent speakers. In comparison to this concept of competence, the competent citizen needs to be conceived as someone who knows how to participate in sub-spheres of shared life, be it the economic sphere or the sphere of public debate, more recently, the problematic sphere of access to and profit from the natural environment.

Yet, on the other hand, a competence also denominates something that a person must have, must possess in order to be in a position to fulfill a distinct task and to perform accordingly. This second aspect has a distinctively normative side. It also resonates with an interpretation of the concept of a "competence" in Roman law. In Roman law a competence is the minimum which, for political reasons, no person can be alienated from. Even persons who have lost all political entitlements, be it because of having committed a crime or for other reasons, receive a "competence" as something which the person, as a person, still deserves within a political community. In that first respect, a competence is a minimum guarantee delivered unconditionally to persons as members of that political society. The intriguing aspect of this second aspect of "competence" is that it is not tied to any specific function in society, it is indeed tied to no function at all. Even persons who were imprisoned and persons who were declared "outlaws" should receive this bare minimum (Ritter et al., 2005: p. 920).

In order to clarify the concept of a "competence" in our context, it is helpful to discuss it in the context of closely related ideas. Competences might be regarded as just another concept that frames the guarantees to get access to most basic goods, including Rawls's approach to primary goods (Rawls, 2005: pp. 75-76, 178-190). In that interpretation, the concept of a competence is just another term for participatory rights in primary goods. In focusing on a non-alienable minimum provision, competences appear to come close to that interpretation. Yet, different from rights to external goods, competences do not address access conditions to existing goods or to institutionally provided goods. Instead, competences are minimum provisions that enable citizens to perform successfully and according to standards of best performances in various spheres of political life. The minimum provision is an enabling condition in order to be in a position to realize qualified performances. An ecological citizen knows how to perform in spheres of life in which issues of environmental concern are central. She also knows her environmental rights and she is in a position to claim them. The educated citizen knows to reason in the public sphere. And the economic citizen profits from the economic sector in a way that coheres with the 
goods that this sector delivers.

Another comparable concept is the concept of a "capability". ${ }^{12}$ Even though both concepts emphasize the process of performances in the political society, one big difference is that competences are not conceived as a fundamental anthropological category. Whereas capabilities rely on an anthropological concept of persons, this does not have to be presupposed in discussing competences. Instead, competences are framed against the background of distinct sub-spheres of society; they are not all-encompassing regarding personal life. Competences do not cover human lives as a whole. ${ }^{13}$ The category rather focuses on persons as participating in spheres of life and exchange, which in turn are regarded as being shaped by political institutions. In an important respect, the category of a competence is more modest than the category of a capability. A competence is a specific, yet basic skill that persons can and need to acquire in order to perform in distinct spheres of social and political life. ${ }^{14}$ Yet, similarly to theories on citizens' capabilities, the duties of governments to support persons in developing skills are taken seriously. The extensionist thesis encapsulates the normative claim that normative concepts, including rights, duties and virtues, need to be extended to concrete spheres of exchange among citizens and to various goods that societies offer, including education. The normative claim is that governments need to care for a range of differentiated skills of citizens in order to fully participate in the fruits and obligations in various sub-spheres of social life.

Finally, competences are capacities to take on functions in modern societies. Yet, different from the idea of a political "office" that citizens can choose to enter and that they can leave on will (Dobson, 2003), citizens are considered participants in complex societies that are both internally differentiated and whose differentiation is part of the success of these societies.

Before discussing the consequences of this interpretation of citizenship, it is necessary to discuss two objections. Firstly, one is tempted to state that the debate on citizenship competences should best be reduced to a broad debate on citizenship education. None of the competences can be achieved without good educational institutions that support basic skills of citizens and that support special skills in order to participate in the private sector or in other professional sectors successfully. In my view, this claim is right; education is a background condition for a host of citizenship competences. Yet, following the debate on virtues and skills, education does not suffice, either. Instead, the concept of a competence includes preparedness to profit from spheres of life successfully, but also to contribute to shaping the spheres of exchange. A competent citizen ${ }^{12}$ Since Martha Nussbaum and Amartya Sen introduced this category to political philosophy, the debate has not come to an end. For the interpretation of that category see Nussbaum (2000).

${ }^{13}$ At some points, it sounds as if Martha Nussbaum also focuses on political entitlements rather than a comprehensive, even though basically good life (see Nussbaum, 2003, 1990).

${ }^{14}$ According to the proposals in Section (1), the distinction between subspheres of social life and political life is shaped according to the idea of a highly differentiated society; yet, each sphere is regarded as part of political society as spheres that need to be shaped according to normative concepts, including concepts of rights, participatory rights, duties and even virtues. 
knows about her opportunities and her obligations, but also contributes to shaping and developing the concrete sphere of social life. ${ }^{15}$

Another issue is the question of whether or not the nation state really should get involved and how it should get involved in building citizenship competences. Here, a "democratic paradox" needs to be recalled, one that has been discussed already in other contexts: Democracies have to fulfill the paradox duty to support the conditions of their survival. Yet, this duty can always be misused. In my view, the category of a competence provides sufficient realm for not getting into that trap. Instead, in working on highly differentiated spheres of exchange and performance, and by highlighting the minimal character of competences, a bulwark is already included. In order to give a full picture, one important issue still needs to be discussed: Who is responsible for claiming competences as enabling conditions of good citizenship performances? This and further challenges to the concept will be discussed in the final section.

\section{Theoretical Implications and Objections}

Before highlighting normative claims, I wish to emphasize what the emphasis on qualified concepts of citizenship and the discussion of citizenship competences does not amount to. It is certainly not meant to get rid of the "big programs" of democracy that defend a normative concept of citizenship. Quite the opposite is true: The approaches to qualified concepts of citizenship highlight the urgency to reformulate normative claims including basic rights and duties of citizens under new conditions of societal life. In particular, they defend an extensionist approach to qualified notions of citizenship in that they address sub-spheres of societies in order to portray normative challenges inherent in these areas of citizenship. As such, they react to the claim to apply insights of applied ethics to political philosophy; simultaneously they also reply to an ever growing concern regarding the future of complex societies.

Yet, in another respect, the approaches to qualified concepts of citizenship try to break new ground in political philosophy. In three respects, the debate on citizenship competences tries to take a new stance on the old question of conceptual needs for addressing citizenship accordingly.

Firstly, due to a more and more differentiated society and due to the emergence of new problematic fields of cooperation including environmental challenges, citizenship theories need to transcend the discussion of broad and most basic concepts that cover a variety of normative claims. Instead, what is needed are categories that allow for specifications, both regarding the content of a variety of new challenges, as also for the ways of acquiring necessary skills. The category of a competence can be extended as to cover social justice, female citizenship, digital citizenship etc. ${ }^{16}$

Secondly, instead of broadening the concern of citizenship theory by remodeling transnational and even cosmopolitan citizenship (Caney, 2005; Benhabib,

${ }^{15}$ This is one of my claims in [Deleted for blind review].

${ }^{16}$ For a discussion of these sub-spheres of citizenship, see [Deleted for blind review]. 
2006), this approach focuses on more concrete, yet distinct units, which are addressed as concrete spheres of citizenship concern. Competences are focused on specified areas of political and social life which confront persons with particular challenges. They are not necessarily related to spheres within a nation state, but can also be tied to spheres of performances which work on a supra-national, perhaps even global level. ${ }^{17}$ But different from former concepts of citizenship rights, the normative exigencies that are enshrined in competences are universal in another respect: on the one hand one can argue that modern societies become much more similar to each other than former societies in a non-global world. Whereas nation states are still in a particular way responsible for their citizens, ${ }^{18}$ the responsibilities among different states become more and more comparable to each other. On the other hand, talking about competences includes talking about very basic requirements.

Thirdly, I propose that an adequate theoretical approach for reasoning citizenship competences is ultimately presented as a list-theory. The unifying factor is the category of a competence; but following a content-rich debate of various citizenship competences in political philosophy also includes "free citizenship" in terms of basic positive and negative freedoms, "equal citizenship" in terms of fair distribution of most basic assets, and in addition to the already discussed competences also "feminist citizenship" and "digital citizenship". ${ }^{19}$ In particular, the content differs significantly from a list of basic rights in that it highlights the functional elements of citizenship as related to spheres of political life. ${ }^{20}$

So far, I have tried to outline the concept of "competences" as a contribution to the debate on citizenship. I have tried to make its content explicit and I have tried to relate it to the alternatives in choosing a theoretically basic category. Yet, one important issue has still been saved, which is the question of its normative implications. Presupposed, the background assumptions that citizenship needs to be framed in normative terms is covered by the extensionist thesis; and presupposed it is possible to render the implicit duties and virtues concrete in discussing qualified citizenship in its various sub-debates, including environmental citizenship, educated citizenship, and economic citizenship and many more. This still does not answer the question of the burden-sharing in terms of qualified duties to support and to develop competences: Who should care for qualified citizenship? Is it the governments, is it civil society, or is it each citizen re-

\footnotetext{
${ }^{17}$ This provides, of course, further challenges as for reasoning basic entitlements and duties. Recent approaches to cosmopolitanism provide a theoretical frame (see, e.g. Benhabib, 2006; Caney, 2005). ${ }^{18}$ The claim that in a global world, norms of citizenship also imply a distinct and differentiated approach to cosmopolitanism has recently been argued for by (Miller, 2016). It would be important to investigate how citizenship theory in a global world plays out regarding the claims on nation states or supranational organizations to support citizens in developing competences. In this contribution, I shall not expand on the "supply-side", but rather focus on the "demand-side."

${ }^{19}$ Following the proposal of a list-theory in terms of capabilities, my suggestion also includes the idea that the list of competences comes with deep evaluation, but is an open-ended list. For this claim as related to the capability list, see Nussbaum $(2000,1990)$.

${ }^{20}$ One way to render the spheres more concrete and to choose them accordingly is provided/presented by the categorization of a range of "public goods" in society [Deleted for blind review].
} 
spectively?

These questions cannot be answered on general grounds. Instead, it is helpful to distinguish two scenarios, which I will call the "ideally democratic scenario" and the "battle scenario". In the "ideally democratic scenario", it is presupposed that in a constitutional democracy, an elected and legitimate government shares the most basic democratic aspirations. It pays respect to its restricted role in framing the performances of various sub-spheres by means of a supportive politics that cares for the rights of citizens; and it tries to keep path with its promises as a government of a diverse society. In this rare ideally democratic scenario, governments are wise to support citizenship competences in all possible ways. The reason for doing so is interest in a lively democracy and in good performances of citizens in various sectors of society. In particular, wise governments know that there is no better way to support development than by supporting the forces within society: Citizens who are capable of participating actively and skillfully in all sorts of sub-spheres, including democratic debates, provide the sources of all sorts of future-oriented developments. Governments are wise to enable and support "full citizenship".

Yet, in the much more realistic "battle scenario", citizens need to claim their rights, including the right to get support for developing citizenship competences; they even have to develop mechanisms to substitute for deficiencies of governments. In one respect, the battle scenario is not only much more realistic, it is also the only realistic bulwark for restricting governmental misuse of sub-spheres of social life: When private institutions care for education and when the economic sector provides spaces for citizens to participate in the performances and fruits of participation, the danger that governments manipulate these spheres of social life is somehow banned. Yet, there is one critical point in the battle scenario: In order to claim the support for competences, citizens need to know a lot about their rights. They already need to be competent in the most basic respects. There are some real dangers in the battle scenario to hollow out citizenship competences: When citizens need to fight for their survival on a daily basis, when citizens are completely frustrated by social injustice or when citizens are not in a situation to know their right to a rich set of competences, the battle scenario endangers citizenship in the interpretation of this contribution.

To give a brief answer on who should support citizenship competences, the answer is that it is the duty of governments to enable citizens to fully participate in political life, and that it is the duty of the society and its leaders to guarantee access to a full range of citizenship competences, including education and environmental knowledge. Yet, citizens need to claim support for citizenship competences.

\section{Conclusion}

The proposal to add "citizenship competences" to the already rich normative debate on citizenship has some positive side-effects on theories as well as on the 
practices of democratic citizenship. First of all, it allows a more concrete discussion of the various normative spheres of citizenship. It reacts to the on-going debates on qualified notions of citizenship in the context of political philosophy. The discourse also highlights the possibility to deliver a more concrete picture of citizenship, even though still sticking with broad normative claims that have been reasoned in general approaches to constitutional democracy. In particular, it also adds in a specific way to the discussions on a "spacious liberalism". Education, health care etc. are themes that give more space for political liberalism by specifying its content.

Simultaneously, there are close ties between the core issues and big programs in political philosophy and the applications of these programs in practice. A closer look on the competences of citizens delivers a concrete picture of the different spheres of learning, practicing and engaging in citizenship. By framing a "bare minimum" of equipment in each respective sphere, the debate can be tied to the discussion on basic rights. Citizens need support not only in order to achieve a good life, but also in order to realize skillful participation in areas of life, that are the pillars of democracy today, that is not only participation in the public spheres as educated citizens, but also in the economic sphere, in art and culture, and in a healthy and sustained environment. In particular, the acknowledgement of citizenship competences is also a proposal to negotiate duties and rights anew: The enabling state needs to support capacities to fully participate in political life and also capacities to shape common spheres of life, including the economy and the environment. Even though an enabling state always comes with the danger of intrusion in spheres of private life, a thorough exploration of the spheres of competent citizenship helps to distinguish basic elements from freedom-related performances in each field of competence. The bottom line is the insight that a normative concept of citizenship has many facets, each of which deserves a thorough exploration.

\section{Conflicts of Interest}

The author declares no conflicts of interest regarding the publication of this paper.

\section{References}

Appiah, K. A. (2007). Cosmopolitanism: Ethics in a World of Strangers. New York: W.W. Norton \& Co.

Aristotle (2013). Aristotle's Politics (Lord, C., Ed. \& Trans.). Chicago, IL: The University of Chicago Press. https://doi.org/10.7208/chicago/9780226921853.001.0001

Barber, B. R. (1999). Clansmen, Consumers, and Citizens. Three Takes on Civil Society. In R. K. Fullinwider (Ed.), Civil Society, Democracy, and Civic Renewal (pp. 9-29). Lanham, MD: Rowman \& Littlefield.

Barry, J. (1999). Rethinking Green Politics: Nature, Virtue, and Progress. Thousand Oaks, CA: SAGE. https://doi.org/10.4135/9781446279311

Bell, D. R. (2005). Liberal Environmental Citizenship. In A. Dobson, \& Á. Valencia Sáiz 
(Eds.), Citizenship, Environment, Economy (pp. 23-38). Abingdon-on-Thames! Routledge. https://doi.org/10.1080/09644010500054863

Benhabib, S. (2006). Another Cosmopolitanism (Post, R., Ed.). Oxford: Oxford University Press. https://doi.org/10.1093/acprof:oso/9780195183221.001.0001

Cafaro, P., \& Sandler, R. (2010). Virtue Ethics and the Environment. Berlin: Springer. https://doi.org/10.1007/978-94-007-0420-6

Caney, S. (2005). Justice beyond Borders: A Global Political Theory. Oxford: Oxford University Press. https://doi.org/10.1093/019829350X.001.0001

Caney, S. (2010). Cosmopolitan Justice, Responsibility, and Global Climate Change. In S. M. Gardiner, D. Jamieson, \& S. Caney (Eds.), Climate Ethics. Essential Readings (pp. 122-145). Oxford: Oxford University Press.

Dobson, A. (2003). Citizenship and the Environment. Oxford: Oxford University Press. https://doi.org/10.1093/0199258449.001.0001

Doherty, B., \& de Geus, M. (1996). Democracy and Green Political Thought: Sustainability, Rights, and Citizenship. Abingdon-on-Thames!: Routledge.

Eckersley, R. (2004). The Green State: Rethinking Democracy and Sovereignty. Cambridge, MA: MIT Press. https://doi.org/10.7551/mitpress/3364.001.0001

Friedman, M. (2002). Capitalism and Freedom. Chicago, IL: University of Chicago Press. https://doi.org/10.7208/chicago/9780226264189.001.0001

Friedman, M., \& Friedman, R. D. (1990). Free to Choose. A Personal Statement. New York: Harcourt Brace Jovanovich.

Galston, W. A. (1991). Liberal Purposes. Goods, Virtues, and Diversity in the Liberal State. Cambridge: Cambridge University Press. https://doi.org/10.1017/CBO9781139172462

Gleick, P. H. (1998). The Human Right to Water. Water Policy, 1, 487-503. https://doi.org/10.1016/S1366-7017(99)00008-2

Gutman, A. (1989). Undemocratic Education, Liberalism and the Moral Life (Rosenblum, N.L., Ed., pp. 71-88). Cambridge, MA: Harvard University Press.

Gutman, A. (1999). Democratic Education. Princeton, NJ: Princeton University Press. https://doi.org/10.1515/9781400822911

Habermas, J. (1994). Citizenship and National Identity. In B. van Steenbergen (Ed.), The Condition of Citizenship (pp. 20-35). Thousand Oaks, CA: Sage Publications. https://doi.org/10.4135/9781446250600.n3

Hailwood, S. (2005). Environmental Citizenship as Reasonable Citizenship. In A. Dobson, \& Á. Valencia Sáiz (Eds.), Citizenship, Environment, Economy (pp. 39-54). Abingdon-on-Thames!: Routledge. https://doi.org/10.1080/09644010500054921

Havel, V. (2000). Politics, Morality, and Civility. In D. E. Eberly (Ed.), The Essential Civil Society Reader. Classic Essays in the American Civil Society Debate (pp. 391-402). Lanham, MD: Rowman \& Littlefield Publishers.

Kallhoff, A. (2011). Why Democracy Needs Public Goods. Lanham, MD: Rowman \& Littlefield Publishers.

Macedo, S. (1990). Liberal Virtues. Citizenship, Virtue, and Community in Liberal Constitutionalism. Oxford: Clarendon Press.

MacIntyre, A. C. (1995). Is Patriotism a Virtue? In R. Beiner (Ed.), Theorizing Citizenship (pp. 209-228). New York: State University of New York Press.

MacIntyre, A. C. (2007). After Virtue. A Study in Moral Theory. Notre Dame, IN: University of Notre Dame Press. 
Marshall, T. H. (1964). Class, Citizenship, and Social Development. New York: Doubleday \& Company.

McCosker, A., Vivienne, S., \& Johns, A. (2016). Negotiating Digital Citizenship: Control, Contest and Culture. Lanham, MD: Rowman \& Littlefield International.

Miller, D. (2016). Strangers in Our Midst: The Political Philosophy of Immigration. Cambridge, MA: Harvard University Press. https://doi.org/10.4159/9780674969827

Nussbaum, M. C. (1990). Aristotelian Social Democracy. In R. B. Douglass, G. M. Mara, \& H. S. Richardson (Eds.), Liberalism and the Good (pp. 203-252). Abingdon-on-Thames: Routledge. https://doi.org/10.4324/9780429278433-10

Nussbaum, M. C. (1996). Patriotism and Cosmopolitanism. In J. Cohen (Ed.), For Love of Country. Debating the Limits of Patriotism (pp. 2-17). Boston, MA: Beacon Press.

Nussbaum, M. C. (1997). Cultivating Humanity: A Classical Defense of Reform in Liberal Education. Cambridge, MA: Harvard University Press. https://doi.org/10.2307/j.ctvighth8

Nussbaum, M. C. (2000). Women and Human Development. The Capabilities Approach. Cambridge: Cambridge University Press. https://doi.org/10.1017/CBO9780511841286

Nussbaum, M. C. (2003). Capabilities as Fundamental Entitlements: Sen and Social Justice. Feminist Economics, 9, 33-59. https://doi.org/10.1080/1354570022000077926

Pettit, P. (1997). Republicanism. A Theory of Freedom and Government. Oxford: Oxford University Press.

Plato. (2008). Republic (Watersfield, R., Ed. \& Trans.). Oxford: Oxford University Press.

Rawls, J. (1999). A Theory of Justice. Cambridge, MA: The Belknap Press of Harvard University Press.

Rawls, J. (2005). Political Liberalism. Expanded Edition. New York: Columbia University Press.

Ritter, J., Gründer, K., \& Gabriel, G. (2005). Historisches Wörterbuch der Philosophie.

Seligman, A. (1992). Idea of Civil Society. Princeton, NJ: Princeton University Press.

Sewing, W. (1993). John G. A. Pocock und die Wiederentdeckung der Republikanischen Tradition. In J. G. A. Pocock (Ed.), Die andere Bürgergesellschaft. Zur Dialektik von Tugend und Korruption (pp. 7-72, Blocher, K., Trans.). Frankfurt a. M. et al.: Campus.

Shue, H. (1999). Global Environment and International Inequality. International Affairs, 75, 531-545. https://doi.org/10.1111/1468-2346.00092

Sunstein, C. R. (1988). Beyond the Republican Revival. The Yale Law Journal, 97, 1539-1590. https://doi.org/10.2307/796540

Thompson, A., \& Bendik-Keymer, J. (2012). Ethical Adaptation to Climate Change. Cambridge, MA: The MIT Press. https://doi.org/10.7551/mitpress/9780262017534.001.0001

Ulrich, P. (2008). Integrative Economic Ethics: Foundations of a Civilized Market Economy. Cambridge, New York: Cambridge University Press. https://doi.org/10.1017/CBO9780511488658

Viroli, M. (1999). Die Idee der republikanischen Freiheit. Von Machiavelli bis heute (Hausmann, F., Trans.). Pendo.

von Humboldt, W. (1903). Ideen zu einem Versuch die Grenzen der Wirksamkeit des Staates zu bestimmen. Behr's.

von Humboldt, W. (1969). The Limits of State Action. In J. W. Burrow (Ed.), Cambridge Studies in the History and Theory of Politics (p. 1). Cambridge: Cambridge University Press. https://doi.org/10.1017/CBO9781316036372 
Wissenburg, M. (2006). Global and Ecological Justice: Prioritising Conflicting Demands. Environmental Values, 15, 425-439. https://doi.org/10.3197/096327106779116131

Ziegler, R., \& Groenfeldt, D. (2017). Global Water Ethics. Towards a Global Ethics Charter. Abingdon-on-Thames: Routledge, Earchscan Studies.

https://doi.org/10.4324/9781315469690 